\title{
The balance in the museum
}

\author{
E. Robens $\cdot$ S. Kiefer
}

IVMTT2009 Special Chapter

(C) The Author(s) 2010. This article is published with open access at Springerlink.com

\begin{abstract}
The balance is the oldest real measuring instrument. It is still a widely used instrument in science, industry, commerce and in the household. It has found significance as a symbol in religion, justice, commerce and as an esoteric object. As a balance is always an interesting object it is exhibited in many museums and there exist a lot specialised scales-and-weight museums. We attempt to give a survey of these.
\end{abstract}

Keywords Balance - History - Museum · Pharmacy · Scales

\section{Introduction}

A museum is a "permanent institution in the service of society and of its development, open to the public, which acquires, conserves, researches, communicates and exhibits the tangible and intangible heritage of humanity and its environment, for the purposes of education, study, and enjoyment", as defined by the International Council of Museums [1] The UK Museums Association definition (adopted 1998) is: Museums enable people to explore collections for inspiration, learning and enjoyment. They

Dedicated to the memory of Hans and Irene Jenemann.

E. Robens $(\bowtie)$

Institut für Anorganische Chemie und Analytische Chemie, Johannes Gutenberg-Universität, Duesbergweg 10-14, 55099 Mainz, Germany

e-mail: erich.robens@t-online.de

\section{S. Kiefer}

Untere Halde 13, 72459 Albstadt, Germany

e-mail: skiefer@vr-web.de are institutions that collect, safeguard and make accessible artefacts and specimens, which they hold in trust for society. For technical museums that "inspiration and learning" aspect is especially important just in modern times with its rapid change of techniques. For example, the knowledge of construction of mechanical balances gained over thousands of years may be forgotten soon, because such instruments today are displaced by electronic balances.

\section{History of science museum}

The Museion of Alexandria, Egypt and some similar institutions of Greece may be regarded as the first museums. Most probably the Museion was founded at the beginning of the third century BC and it was conceived and opened during the reign of Ptolemy I Soter (367-283 BC) (Fig. 1), or of his son Ptolemy II (309-246 BC). Museion means sanctuary of the muses. Carved into the wall above the shelves, a famous inscription read: The place of the cure of the soul. Such institutions had more the character of an academy or university and they had been connected with large libraries. The Royal Library of Alexandria [2], Egypt was once the largest library in the ancient world containing about 500000 papyrus scrolls. Mark Antony (83-30 BC) supposedly gave Cleopatra (69-30 BC) over 200000 scrolls taken from the great Library of Pergamon for the library as a wedding gift. Other than collecting works from the past, the library was also home to a host of international scholars, well patronized by the Ptolemaic dynasty with travel, lodging and stipends for their whole families. As a research institution, the library filled its stacks with new works in mathematics, astronomy, physics, natural sciences and other subjects. Most probably there were also scientific 


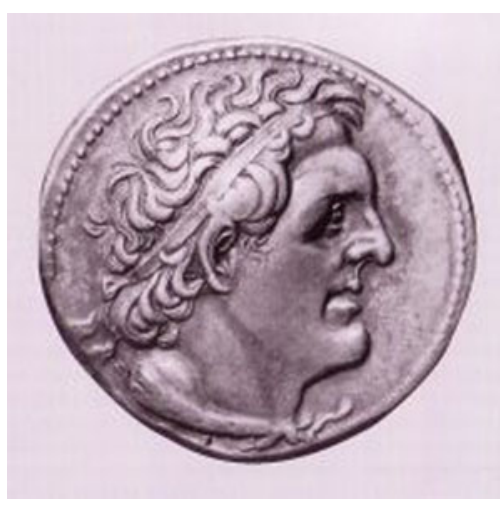

Fig. 1 Tetra drachma with head of Ptolmaios I, Soter, Pharao of Egypt 367-283 BC

instruments, though standardisation work for scales-andweights was carried out in the temples by priests. Heron Alexandrinus (the mechanicus) was a mathematician, physicist and engineer who lived in 10-70 AD. From Heron's writings it is reasonable to deduce that he taught at the Museion in Alexandria and most probably he presented there his inventions.

Plutarch (AD 46-120) wrote that Caesar accidentally burned the library down during his visit to Alexandria in 48 BC. However, this version is not confirmed in contemporary accounts. It has been reasonably established that the library or parts of the collection were destroyed on several occasions. Finally, the whole building was destroyed, there exist no image and it is still unknown where it was exactly situated. In 2002, the new Bibliotheca Alexandrina was opened near the site of the Old Library.

In the Roman Republic robbed Hellenistic statues provided the basis for art collections of rich people. Later on, beginning in the fourteenth century, European dynasties made similar collections. In the second half of the sixteenth century, interest in unusual and curious things caused the initiation of "Cabinets of arts and curiosities" in which also old and newly invented instruments found their place. The earliest prototype was the famous "Kunst- und Wunderkammer" in the Castle Ambras, Tirol (Fig. 2) of the archduke Ferdinand II of Austria and Tirol (15641595) [3]. The collection is scattered and scientific objects are exhibited today in the Kunsthistorisches Museum, Wien, Austria and in the Amabras Castle. In the seventeenth and eighteenth century at almost every residence such collections were established. However, these collections had been reserved for aristocrats and privileged people and were not open for the public.

Since the eighteenth century the museum developed to be an institution. The British Museum (Fig. 3) was established in 1753, as the first national, public and secular museum in the world [4]. Also such "public" museums were often accessible only by the middle and upper classes.

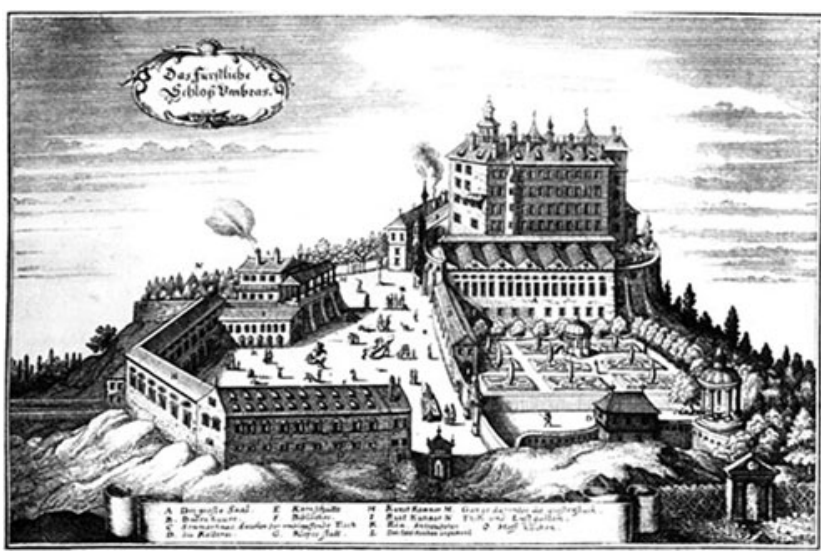

Fig. 2 Castle Ambras, Tirol, near Innsbruck, copper engraving of Matthäus Merian

It could be difficult to gain entrance. In London, for example, prospective visitors to the British Museum had to apply in writing for admission and to wait for a reply for some weeks. Some Egyptian scales-and-weights are exhibited there and in particular many papyri containing drawings of scales. As a result of the French Revolution in France the museums were opened for the public, e.g. the Muséum Français in the Louvre (Fig. 4). This was the first truly public museum, opened in 1793, which enabled for the first time in history free access to the former French royal collections for people of all stations and status. In the Louvre are exhibited the probably oldest bas-relief of a balance in the hand of a Hethytic weigher. Furthermore, Leonardo's sketches of gravimetric hygrometers are stored there.

In the nineteenth century, many specialised museums were founded. The Smithsonian Institution founded 1846 at Washington, USA, began to establish several museums, e.g. the National Museum of American History which includes collections of scientific instruments. 1857 the Science Museum, London started with technical objects shown at the Great Exhibition held in the Crystal Palace. There are exhibited several Old-Egyptian balances and a copy of the oldest balance. In the Musée des Arts et Métiers, Paris, the balances of Lavoisier are shown and as well the first vacuum balance of Deleuil and Regnault. A

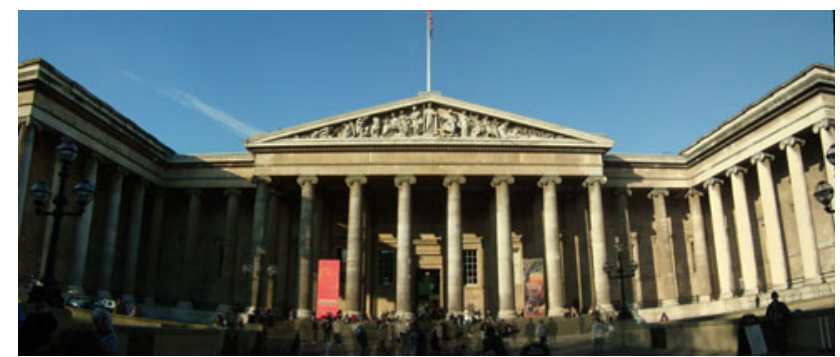

Fig. 3 British Museum, London, 1753, first national, public and secular museum in the world 


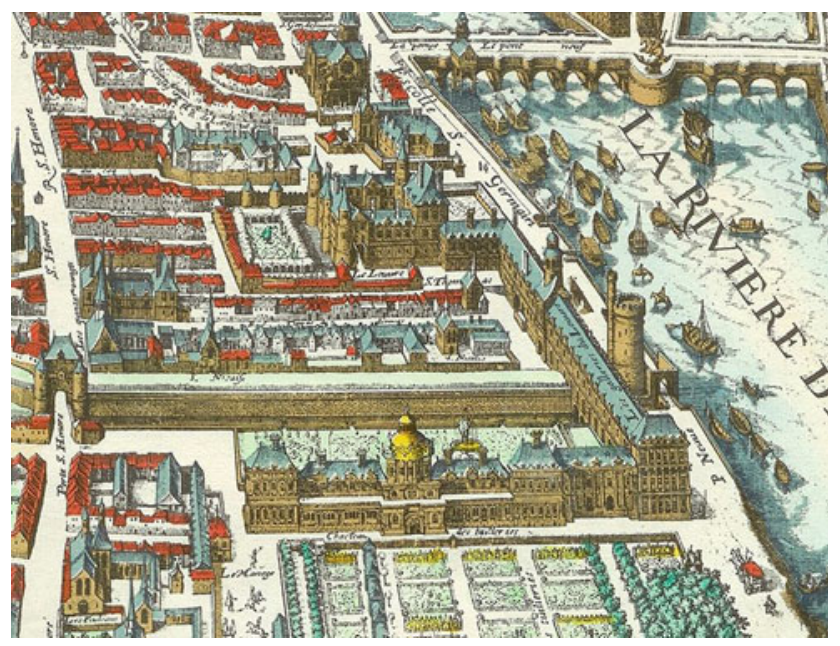

Fig. 4 Louvre, Paris.1815. Louvre, Paris 1815. First truly public museum, opened in 1793

more modern example is the exposition of the Bureau International des Poids et Mesures at Sèvres. Of course, all standardisation authorities possess collections of old instruments and they present their standard equipment The Deutsches Museum at Munich (Fig. 5) was opened in 1906 [5]. The large collection of scales includes Gast's electromagnetic and suspension balances.

\section{Present situation}

In the twentieth century, many specialised collections were installed e.g. several scale and weight museums [6] and numerous pharmaceutical museums [7]. Today nearly every village has a local museum or a collection in the town hall and in each of those small and lovely museums you will find some household and commercial scales. Many drug stores exhibit small collections of balances stored after their use sometimes for more than a 100-years.

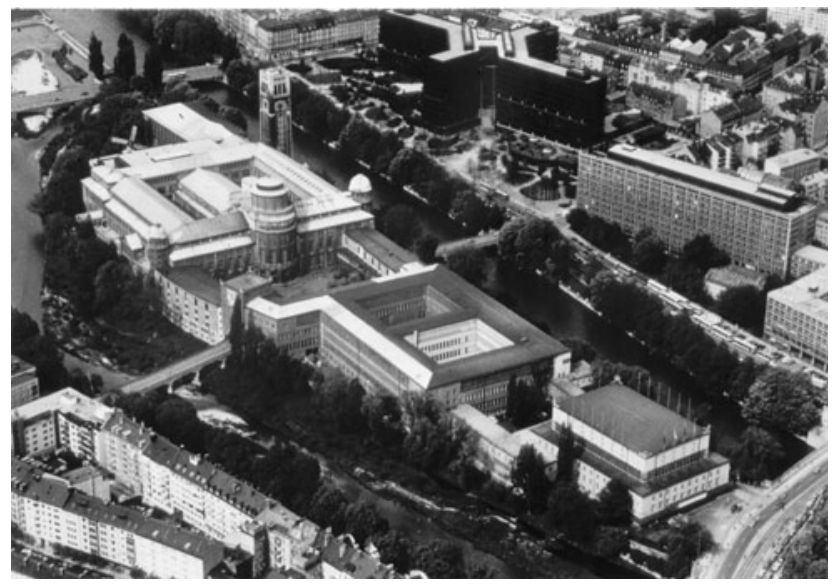

Fig. 5 Deutsches Museum, Munich, Germany, opened 1906
A recent development, with the expansion of the web, is the establishment of virtual museums.

History and progress of development of scales are documented in the extensive popular and scientific literature. As recent standard work, Kochsiek and Gläser's Comprehensive Mass Metrology [8], Jenemann's The Chemist's Balance [9] and the Proceedings of the International Conferences on Vacuum Microbalance Techniques [10] should be mentioned.

The progress in mechatronics caused a rapid change from pure mechanical scales to mechatronical designs which conquered the market of laboratory balances. The sensitivity of force cells with strain gauge was improved so that they satisfied the requirements of industrial and household scales. With oscillating sensors the range was extended below the microgramme. The main advantage of these new types of balances was easy and fast operation and recording of the result which allowed for online evaluation of results and its use for process control. Therefore, suddenly a large number of obsolete laboratory and other scales submerged into the antique market. A lively scene of collectors of historical instruments and respective societies arose. In particular weights and scales were regarded by people interested in history of techniques. Some of these collections are of scientific importance besides the historical aspect. The balance collection of the Deutsches Museums, Munich, Germany documents the progress in science in instrumental techniques. The

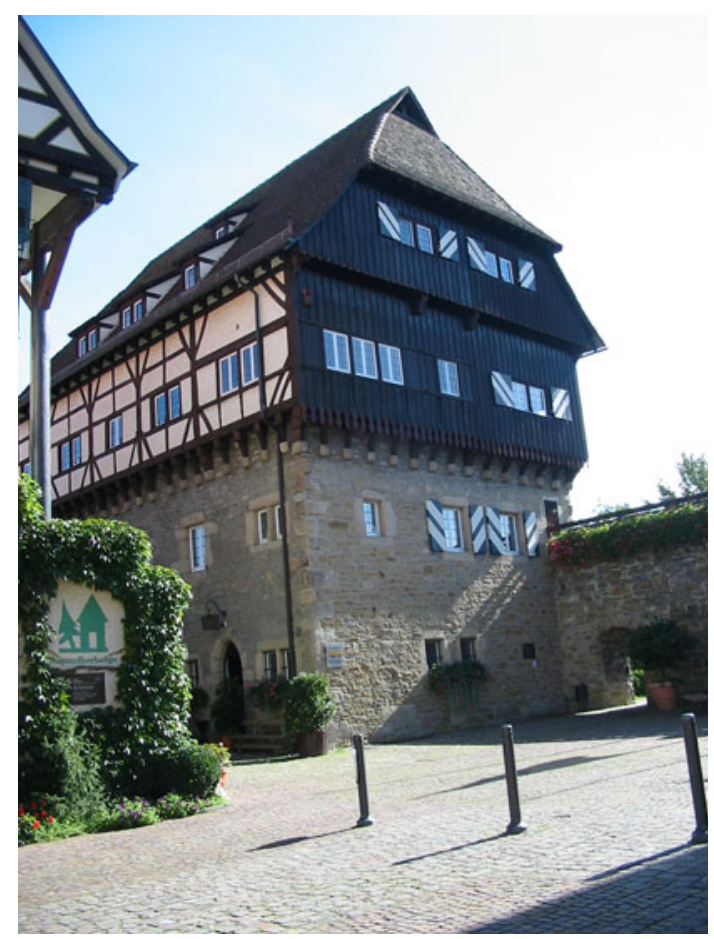

Fig. 6 Museum für Waage und Gewicht, Balingen, Germany 
Jenemann and Dannehl collections in Frankfurt and Albstadt, Germany [11] include nearly thousand laboratory scales and provide a survey on the development of mechanical balances. Important weight and scales museums covering the whole field of mass determination are in Balingen, Germany, (Fig. 6) and Campogalliano, Italy. The balance collection of the Egyptian Museum, Cairo, gives a survey of the early development of such instruments. Since much Egyptian artwork is displaced and scattered

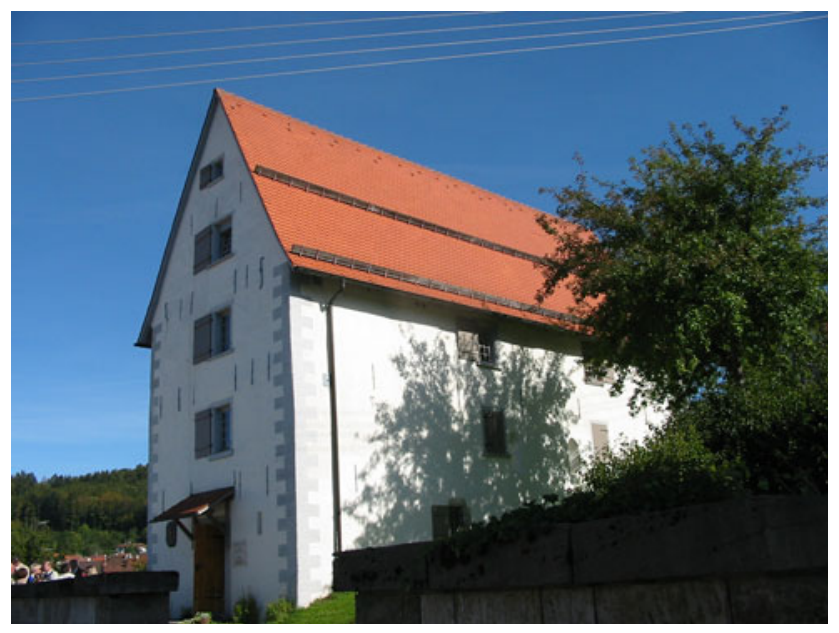

Fig. 7 Philipp-Mathäus-Hahn-Museum, Im Kasten, Albstadt-Onstmettingen, Germany

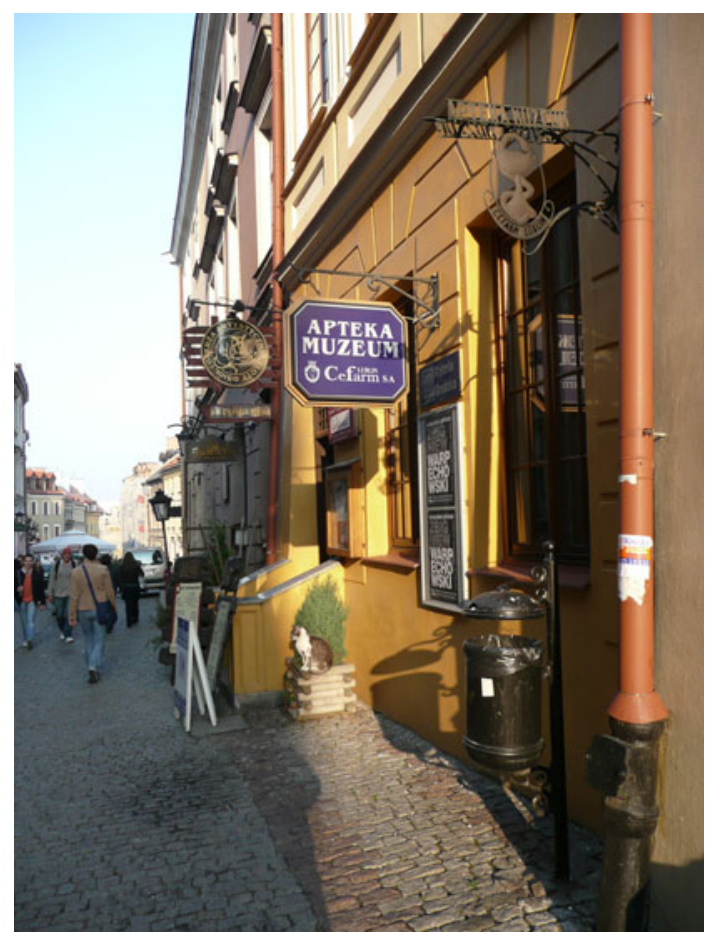

Fig. 8 PZF “CEFARM” Apteka Muzeum, Lublin, Poland throughout the world, we find in particular depictions of the Egyptian "Death balance" on papyri and on sarcophagi in many museums in every country.

Other collections are centred on inventors, e.g. the Philipp-Mathäus-Hahn-Museum at Onstmettingen, Germany (Fig. 7). Hahn was a protestant priest, ingenious inventor of astrolabes, watches, balances, calculators and he is regarded as the initiator of precision mechanical industries in the Swabian Alb. Furthermore, many laboratory scales are included in pharmaceutical museums and in historical drugstores which are found everywhere in the world. As an example, we mention the Apteka Muzeum, Lublin, Poland (Fig. 8).

\section{Conclusions}

The development of scales is well documented in the literature and by artefacts of instruments and weights everywhere in museums. Extensive, but nevertheless incomplete lists of museums which exhibit large collections of balances are given in references [6,7]. They include museums in the following countries: Argentina (1), Australia (5), Austria (6), Belgium (3), Brazil (2), Canada (4), Chile (1), China (2), Costa Rica (1), Croatia (2), Czech (4), Denmark (13), Egypt (1), Finland (25), France (35), Germany (57), Greece (1), Hungary (8), Iceland (2), Italy (14), Japan (1), Lithuania (2), Luxemburg (1), Netherlands (6), Norway (7), Poland (5), Portugal (1), Puerto Rico (1), Romania (2), South Africa (3), Spain (13), Switzerland (4), Slovakia (1), Sweden (26), Ukraine (2), United Kingdom (7), USA (29) and Virgin Islands (1).

Open Access This article is distributed under the terms of the Creative Commons Attribution Noncommercial License which permits any noncommercial use, distribution, and reproduction in any medium, provided the original author(s) and source are credited.

\section{References}

1. http://en.wikipedia.org/wiki/Museum. 2009.

2. http://en.wikipedia.org/wiki/Ancient_Library_of_Alexandria. 2009.

3. Primisser A. Die kaiserlich-königliche Ambraser-Sammlung. Wien: Heubner; 1819.

4. Caygill M. Creating a great museum: early collectors and the British Museum. The British Museum. 2009. http://www.fathom. com/course/21701728/index.html.

5. Klemm F. Geschichte der naturwissenschaftlichen und technischen Museen. Abhandlungen und Berichte-Deutsches Museum. 1973;41:2.

6. http://www.mass-und-gewicht.de/, Maß und Gewicht - Zeitschrift für Metrologie.

7. PerBos Farmacihistoriska Sidor. http://home.swipnet.se/Pharm Hist/. 
8. Kochsiek M, Gläser M, editors. Comprehensive mass metrology. Berlin: Wiley-VCH; 2000.

9. Jenemann HR. Die Waage des Chemikers-The Chemist's Balance. DECHEMA: Frankfurt am Main; 1997.
10. Chądzyński GW, Robens E, Jayaweera SAA. Preface. J Thermal Anal Calorim. 2006;86(1):1-6.

11. Robens E, Kiefer S. Die Sammlung Jenemann ist nun in Onstmettingen. Maß \& Gewicht. 2009;89:2195-6. 